\title{
Digital teaching competence of university teachers: A systematic review of the literature
}

\author{
Francesc M. Esteve-Mon, María Ángeles Llopis-Nebot, Jordi Adell-Segura
}

\begin{abstract}
The digital teaching competence is an emerging issue in scientific literature. However, despite existence of different frameworks that define it, most of them are focused on the pre-university level. This article presents the results of a systematic review of the literature on the digital teaching competence of university teachers, in the Web of Science and Scopus scientific databases. According to the results, university teachers must be competent enough to meet the new challenges of today's digital society. This digital competence, both technical and pedagogical, allows teachers to enrich their teaching, develop the digital competence of their students and continue to develop professionally. Regarding their level of digital teaching competence, most university teachers seem to have adequate technical digital competence. Nevertheless, the results regarding the pedagogical use of technologies are different, with lower levels being found in the use of technologies for their own teaching development.
\end{abstract}

Index Terms - digital competence, teaching, higher education, professional development, university teachers.

\section{INTRODUCTION}

$\mathrm{O}$ $\mathrm{NE}$ of the most common competences included in frameworks that outline recommended skills in the educational field is digital competence. To be sufficiently prepared for the challenges and demands of today's society, competence in technology is imperative [1]. According to the European Commission's Joint Research Center [2], competence in technology is: the combination of knowledge, skills and attitudes required to use digital skills in an appropriate, safe, decisive and responsible way in the educational, professional and social sectors. It is also a competence that includes different literacies: information, communication and collaboration, media, security, intellectual property, problem solving and critical thinking [3].

Despite these clear delineations, there is still no one, definitive understanding of digital literacy. In fact, even though a widespread concept is accepted in European education, the term "digital literacy" is more common in other

F. M. Esteve-Mon is Assistant Professor at Universitat Jaume I, Av. Sos Baynat s/n, 12071, Castelló de la Plana, Spain (corresponding author to provide phone: +34 964729899; e-mail: festeve(auji.es).

M. A. Llopis-Nebot, Lecturer at Universitat Jaume I, Av. Sos Baynat s/n, 12071, Castelló de la Plana, Spain (e-mail: mallopis@uji.es).

J. Adell-Segura, Associate Professor at Universitat Jaume I, Av. Sos Baynat s/n, 12071, Castelló de la Plana, Spain (e-mail: jordi@uji.es).

DOI (Digital Object Identifier) Pendiente contexts. According to some authors, it does not always have the same connotations or the same level of abstraction as in European education, although it is often used synonymously. For authors such as Bawden [5] or Martin [6], digital literacy implies the awareness, attitude and ability to use technological tools appropriately to identify, access, critically evaluate, manage, integrate, and synthesize digital resources, build new knowledge, express oneself in multiple media and formats, and communicate in a regular and simple way.

In addition to this competence being so essential to every citizen in the 21 st century so that they are able to engage in global platforms, it is especially important for teachers today to integrate technology into their professional practices, and so it is crucial that they update their digital skills to meet current and future challenges [7]. This is why the concept of "digital teacher competence" has emerged so strongly in recent years.

In English we find different denominations to refer to the concept, using the terms "digital competence" or "digital literacy" when applied to teachers [9], educators [10], faculty [11], or professors [12], among others. For this study, "digital teacher competences" can be understood to mean: the set of skills, attitudes and knowledge required by educators to support student learning in a technologically rich world, design and transform classroom practices and enrich their own professional development [13]. Krumsvik [9], distinguishes between different levels in this competence: basic skills in handling technology, didactic digital competence and lifelong learning strategies. This distinction includes the competence of teachers and teacher-trainers in general; in other words, not just digital mastery, but their didactic choices as well.

Adding to the European DigCompEdu framework, Redecker and Punie [10] insist that it is the teacher's responsibility to empower learners to develop their own competences in technology, apart from what they, themselves, have mastered. They stress that being a digitally competent teacher means being able to help students to develop their own digital competence, which certainly doubles the stakes for resistant teachers in invest time in improving these skills.

Regardless of the existence of different frameworks and models that define this competence [14, 15], most are focused on the pre-university level for different reasons. Today's universities - which are structured by different organizational models and traditions - often give more importance to research than to teaching methodologies. According to Mattila [16], the result is that, in many cases, not enough attention is paid to the didactic abilities of teachers, especially in including digital 


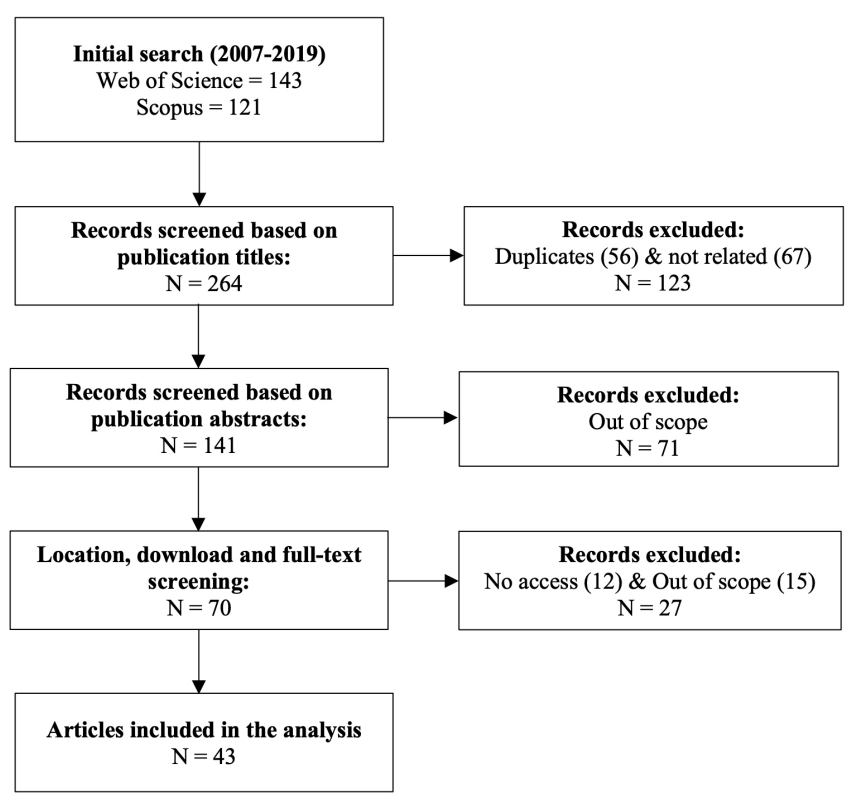

Fig. 1. Diagram of the review process

skills and resources in the designing of lessons, the creation of materials, and monitoring and communication with students; these are considered to be of less value than the publication of scientific articles. In addition, most of the existing literature on the implementation of digital technologies in higher education environments focuses on student learning, rather than on faculty teaching [17].

\section{MethoD}

The purpose of this study is to analyze the digital teaching competence of university teachers. To this end, the results of a systematic review of literature on digital teaching competence of university teachers are hereby presented. This is a type of exhaustive review that not only aims to synthesize empirical results, but also to analyze and critically contrast the literature selected on the basis of specific research questions [18]. Concretely, this review attempts to answer the following questions: (1) What are the reasons used to justify the digital teaching competence of university teachers; (2) What are the areas or dimensions that make up this competence; and (3) What is the level of the digital teaching competence of university teachers?

The research was carried out through the databases Web of Science (WoS) and Scopus scientific databases, using the keywords: "digital competence", "digital literacy", "higher education", and "teaching". No date restrictions were applied, so the results include all articles published up to and including July 2019. The search was conducted in English and all articles published in English, Spanish and Portuguese were collected. The initial scan produced 264 references (Figure 1). To be included in this study, publications had to focus on university level information and refer at least once to the justification of the need for teaching digital competence, its definition and/or the evaluation of the necessity for whose competence.

In the first phase of research, all extracted articles were reviewed, and duplicated references, or those not directly related to the subject at hand, were eliminated, leaving a total of 141 relevant sources. In the next phase, all the abstracts were reviewed, eliminating publications not related to the subject, which left 70 sources. These 70 articles were then downloaded and read in their entirety for relevance, leaving a total of 43 articles that would be analyzed in-depth. All of these articles were then added to a database, which allowed for a systemized extraction of relevant information based on characteristics such as: geographical area, type of research, instruments used, size of the sample and its contribution to the subject (justification for the development of digital teaching competences at the university, areas that make up the university, and level of competence of university teachers). In Table 1 we can see the characteristics of this study.

\section{RESULTS}

The results described below have been structured according to the research parameters listed above.

\section{A. Final stage reasons to justify digital teaching competences of university teachers}

One of the recurrent justifications regarding the insistence that university teachers be "digitally competent" is based on the importance placed on their requirement to be able to meet the challenges posed by technology now on a global scale. Higher education institutions and their educators have to accept the changes in the world regarding technology [16] and so consequently need to abide by a new set of educational priorities [19]. According to Mendieta [20], nowadays, educating oneself is more complex and varied than it has ever been before. The new paradigm with its stress on technology, requires new skills and practices, both for the student and the teacher at all educational levels [21, 22, 23]; with this comes the complexity and ambiguity that is now part of today's

TABLE I

CHARACTERISTICS OF THE STUDIES

\begin{tabular}{|c|c|c|}
\hline \multirow{6}{*}{$\begin{array}{l}\text { Geographical } \\
\text { area }\end{array}$} & Africa $(n=1)$ & South Africa (1) \\
\hline & Asia $(n=2)$ & India (1), Israel (1) \\
\hline & Europe $(n=25)$ & $\begin{array}{l}\text { Spain (10), United Kingdom } \\
\text { (6), Romania (2), Croatia } \\
\text { (1), Finland (1), Germany } \\
\text { (1), Greece (1), Ireland (1), } \\
\text { Serbia (1), Ukraine (1) }\end{array}$ \\
\hline & North America $(\mathrm{n}=5)$ & $\begin{array}{l}\text { Mexico (4), United States } \\
\text { (1) }\end{array}$ \\
\hline & Oceania $(\mathrm{n}=2)$ & Australia (2) \\
\hline & South America $(\mathrm{n}=8)$ & $\begin{array}{l}\text { Ecuador (3), Brazil (2), } \\
\text { Argentina (1), Colombia (1), } \\
\text { Nicaragua (1). }\end{array}$ \\
\hline \multirow[b]{2}{*}{ Type } & Theoretical (17) & \\
\hline & Experimental (26) & $\begin{array}{l}\text { Questionnaire (23), } \\
\text { Interview (7), Focus group } \\
\text { (1) }\end{array}$ \\
\hline Participants & \multicolumn{2}{|c|}{$\begin{array}{l}<50(9), 51-100(9), 101-200(4), 201-500(2), 501- \\
2000(2)\end{array}$} \\
\hline
\end{tabular}


society in general [24]. The necessity for digital competences also includes the imperative to respond to the demands of both state administrations and international institutions-an added complexity in the responsibility to develop these skills [25].

However, the reason most often given by the authors of more than half the articles included in this systematic review is that the overriding reason for being digitally competent is to be able to enrich the teaching-learning processes. The digital revolution has substantially changed the current educational panorama [26]; educators not only need basic digital knowledge, but they also have the responsibility of being able to apply technological elements in their lessons, thus expanding on their own pedagogical choices, and facilitating learning processes for their students $[27,28,29,30]$.

One of the most transformative characteristics of educational technology is its potential for communication, interaction and promotion of collaborative work [31, 11]. Educators who are digitally competent should not only use the communication possibilities that already exist in the learning environment in their universities. Instead, they can take advantage of and integrate the wide range of possibilities offered by the social web and its networks [32,33]. These options provide new opportunities for how students can interact with information and broaden efficiency in assessing knowledge [34].

Another characteristic highlighted by the authors included in this study, is that technology allows for innovation in the roles of teachers and students, facilitating the path for more student-centered learning. The teacher can take on the role of a guide and mentor [35, 26, 24], while students become transformers, producers and disseminators of knowledge [36]. This competence, necessary for the improvement of the teaching-learning process, is even more indicated in online training $[12,17]$.

A third reason highlighted by various authors for educators to become proficient in the digital world is the relatively high level of competence students already possess upon entering the university environment. Some authors emphasize how necessary it is, at least to some extent, for university professors to rise to the needs of their students, though often named "digital natives" [37, 38, 11]. Nevertheless, regardless of how university students might be characterized (and some say that assumptions regarding their technological proficiency is inaccurate), digital proficiency is an imperative competence that requires to be embedded in lesson planning throughout their university experience [39]. For instance, educators should be able to promote research skills that their students do not already possess [40], so that they can more efficiently search for, select and share information, and manipulate technology in order to gain a measure of autodidactism [41]. Other authors go further, saying that university teachers must have the skills to train "digital citizens" [42, 43, 38], and to empower them to use digital tools both in their current studies and in their future professions $[32,35]$.

Finally, though less recurring in the literature analyzed for this study, another of the reasons included in the justifications for the need for technological proficiency at the university level has to do with continuous professional development. As digital competences can help university teachers to acquire new skills and update their own professional skills [16, 37] (including activities as diverse as, for example, participating in virtual and face-to-face courses, using portfolios to collect and reflect on their own learning, and critically evaluating their own teaching practices [20], they ought to be a standard training point the continuing development of educators.

\section{B. Areas or dimensions that make up digital teaching competence for university teachers}

According to most of the literature reviewed, we can divide the areas that make up the digital teaching competences for university teachers into four groupings: (1) basic digital skills; (2) the pedagogical application of digital technologies; (3) the use of technology for continuous professional development; and (4) the ability to further digital competences for university students.

Let's begin with the first of these. For some of the authors in the study, digital competences for teachers imply acquiring basic digital skills or skills of a technical nature [37]. This suggests the use of digital tools for searching, selecting, analyzing and processing information $[12,43,19]$ either in a personal or professional context [44]. A related practice is known as "content curation" [24]. It also includes development of communication and social skills $[45,32,11]$ which involves: the use of technology, social networks for collaborative work, and personal communication and interaction among colleagues, the student body and the community in general $[46,44,45]$. Furthermore, it entails the ability to create documents and content using multimedia language in multiple and open formats [43, 47, 19, 11, 48, 35]. In addition to these basic digital skills at the informational, communicative or multimedia level, several of the selected authors point to the crucial importance of being familiar with the ethical, legal, safety and ergonomic aspects of the use of technologies [46, 49, 37].

The second grouping includes all the skills related to the application of digital technology that are found in the teaching-learning processes, covering the design of activities and learning experiences both in face-to-face and virtual environments $[21,49,50]$. There are mentions of the technopedagogical knowledge necessary for an appropriate selection of resources, didactic objectives, chronological sequencing, and their uses [12, 32, 41, 47, 37]. Activities should be inclusive and personalized, according to the characteristics of the student body and their needs [46, 49, 50]. Assessment is also linked to the design of activities and learning situations both the monitoring, facilitating and feedback between teacher and student $[49,51]$, as well as evaluation of activities and teaching practices that involve technology $[21,44]$.

The application of technology in an educator's professional development is the focus of the third grouping. This contains the ability to explore the possibilities technologies offer, experimenting in their own teaching practices [21], and keeping up to date of current trends in the technological field [51]. It also refers to research, critical analysis and reflection 
on one's own practice [49, 47], plus improving and transforming one's skills and abilities $[46,44]$ on a continuous basis $[45,50]$. This grouping touches on the development of a digital professional identity, as well as the use of technology to communicate with other teachers and establish improvement networks [48].

The fourth grouping presents the idea that the responsibility for the development of digital competences for students lies with the teacher $[48,43,39,34]$. More concretely, this refers to teachers having the ability and drive to facilitate technical information, communication and multimedia skills, and to embed these skills in their lessons [21].

\section{Level of digital teaching competences of university teachers}

Finally, in keeping with the categories delineated above, the results of the empirical studies regarding the level of digital competences in the teaching field have been analyzed though they have been collected through different tools and strategies, often based on teachers' self-perception.

In general, the selected sources maintain that the majority of teachers have no more than a medium or medium-to-high level proficiency level with regard to digital mastery [32, 52, 53, 51]. Those skills specifically related to office duties, such as word processing, presentation software, e-mail and file management, are considered to be at an acceptably high level by a large number of teachers $[31,52]$. Other skills related to the use of more social media, such as blogs, wikis, or more sophisticated usages, such as audio or video editing, seem to be largely absent in the technical skill set of educators [31]. The teachers analyzed often expressed reticence in adding digital tasks in the planning of their lessons [43]. Familiarity with security, data protection and intellectual property management were also lacking to a large extent [43, 52]. Furthermore, a subset of the selected articles emphasizes that, despite having acceptable technical skills, to the detriment of the students' advancement in technology, many teachers do not have more experience than undergraduates [21]. For example, although teachers may regularly use basic technology - such as emails -, students are more confident in using it [12]. In any case, many of the authors in the study recognize that educators are not a homogeneous group, as there are differences in age, gender and/or area of expertise in basic digital skills $[54,55,40]$, so definitive conclusions ought not to be made.

As to digital competences of educators in regard to pedagogy, the results were more disparate. Bennett [21] states that teachers who participated in the study have adequate competences in the design of activities that include technology or online learning. However, the pedagogical aspect covers the ability of teachers to explore the didactic capabilities of technologies, design activities adapted to the level of their students, and facilitate learning by using digital tools in an innovative way. Similarly, Montoro, Hinojo-Lucena and Sánchez [29] state that while most teachers consider their mastery of digital technologies as a pedagogical resource to be high, the ability to use ICTs for student assessment and monitoring teaching practices, was determined to be low or very low. Pozos and Tejada [50] confirm this by highlighting the low level of skill of the teachers who participated in their studies. For example, they found deficiencies in teachers' abilities to plan and design learning opportunities that include technology for their students, carry them out in a collaborative manner, and facilitate, guide and assess student learning. In the same way, Wheeler and Vlachopoulos [56] point out the low capacity of teachers to implement technology in their practice. All of this based on a holistic model of teacher competence, beyond planning and curriculum development, but also reflective and critical aspects.

In any case, authors in different studies agree that the level of competences related to technical skills is higher than that of any digital skills comprised in pedagogical practices [32, 37, $50,51]$. Likewise, some of the authors point to gender and age differences in the pedagogical use of technologies, with women and intermediate age groups showing higher scores [55]. But, as noted in the previous section, there is no single way of understanding what it means to make appropriate educational use of ICT. This entails the use or creation of digital resources, knowledge of pedagogical possibilities in relation to the addition of technology, the design and implementation of learning activities enriched by ICTs, the management of spaces and technological environments for teaching-learning, and the assessment and monitoring of students through digital means. Nevertheless, not all research focuses on all of these aspects, nor do the studies evaluate these elements using similar methods or strategies.

In terms of competences in the use of digital tools for professional development, the research suggests that teachers have a low-to-medium level of skill sets. Aspects such as their participation in professional forums or networks, the use of educational platforms and repositories, membership in innovation groups and the dissemination of experiences with technology, all received negative results [52]. Montoro, Hinojo-Lucena and Sánchez [29] also point to the creation and maintenance of teachers' personal learning environments (PLE) is an element that is still largely unexplored.

Finally, the research involves the exploration of the ability of educators to aid in the development of digital competences in their students. In this respect, Rodríguez, Restrepo and Aranzazu [55] suggest that most of the teachers in the study do indeed promote digital technologies in their lessons, especially with regard to consulting bibliographic databases or preparing papers and reports, and to a lesser extent, in collaborative work. But, Deumal and Guitert [43] noted that most of the teachers were skeptical about the necessity to include digital elements in their lessons as students already have strong digital skills upon entering university.

In addition to results focused on assessing the digital competences of university teachers, some research also examined aspects such as frequency of use or perception of usefulness. In line with the previous results, Catalano and Catalano [57], García, Dungay, Elbeltagi and Gilmour [32] and Rodríguez, Restrepo and Aranzazu [55] show that teachers frequently use technology above all for personal and 
office communications, and to a lesser extent for social use. In addition, most of the teachers in the study showed respect for the use and application of technology, both in general $[42,37]$ and in specific areas, such as educational resources and open data [35]. Age-differences were influential with regard to perspectives of educators toward the importance of including technological skill sets in lessons [33].

\section{DISCUSSION}

The goal of this study has been to give an in-depth analysis of digital teaching competences for educators at the university level based on available literature. For this purpose, a systematic review has been carried out, analyzing the conclusions reached through research of digital skills at the university level. These sources were found in and extracted from the scientific databases of Web of Science and Scopus. The focus involved determining the areas or profile that make up digital competences, and the level of development that now exists in the online environment.

The justifications for the analyses in the literature identified regarding the importance of digital competences at the university level are divided into four main groupings: (1) those meeting the new challenges of the digital society, being able to confidently confront the challenges in this sector, and respond to its social demands; (2) those enriching the teaching-learning process, being able to take advantage of the informational and communicational possibilities (especially in online training) and making the change of role of the teacher more effective; (3) developing the digital competence of students as a key competence, as well as empowering them and training them as digital citizens; and (4) promoting either content or professional development by using digital technologies in either face-to-face or virtual venues. According to Selwyn [58], beyond the external and internal justifications for the introduction of digital technologies in higher education, their use seems to have become an accepted and expected inclusion in the curriculum today. In addition to contributing to the modernization of educational institutions, digital technologies have great potential for transforming the teaching-learning processes and providing new learning opportunities [59]. Today, educators at tertialy level need to adapt to these changes and become more deliberately competent in technology, in order to respond to new challenges and demands - something that has been a recurrent theme since the turn of the century [60].

In reference to the second question, digital teaching competences appear to be composed of (1) a series of technical skills, (2) didactic application in the teachinglearning processes, (3) inclusion in professional development, and (4) the ability to develop the digital competences of students. Technical skills include the informational dimension (search, access, selection, storage and management of information), communication skills, interaction and collaboration with others, the ability to create documents and objects with different supports and formats, as well as all ethical and legal aspects derived from them. Didactic use comprises the design of digital environments, activities and learning experiences, implementation, monitoring and assessment of the student, as well as the educational practices themselves, along with elements such as the design of inclusive activities that attend to diversity.

In terms of professional development, the analysis focused on the ability to explore the possibilities of technology, research and reflect on their own practice in the classroom, transform it, and share it with others through networks. These areas or dimensions coincide with those proposed by Krumsvik [9] in his Norwegian model of digital teacher competence. In addition to these, Durán, Gutiérrez and Prendes [61] also add professional dimensions such as research, innovation and dissemination in online communities.

A part of the research gathered suggested the development of digital competences of students as part of teachers' responsibility and competence. In this sense, the European DigCompEdu model [10] - more oriented towards preuniversity teachers - also includes this element, along with the importance of empowering students, a factor that is not always present in the models analyzed for this specific study. According to Castañeda, Esteve and Adell [62], digital teaching competence models often propose the use of technologies in the "classical" aspects of the teaching profile, i.e., teachers in the classroom, forgoing the inclusion of such elements as empowerment or social commitment.

Finally, to answer the third research question, the articles generally of an empirical nature - have been analyzed with respect to the assessment of the teaching digital competence of university teachers. Taking into account the multiple and varied assessment instruments (most of which should be more accurately identified as "self-assessment"), it can be concluded that most of the teaching staff show an adequate digital competence at a basic level, especially in relation to technology used in daily routines, as opposed to in more social contexts.

As for the pedagogical use of digital technologies, there appear to be more disparate results. Some authors in the study $[21,29]$ suggest that teachers possess a high level of competences with respect to the design of learning activities in which technology plays a substantial role, while other authors $[50,56]$ state that there are important training gaps in this regard. In any case, there appear to be a general conclusion that technical skills are superior to sound pedagogical ones. The level is also medium-low with regard to the use of technologies included in continuous professional development, and there is little evidence regarding the capacity of teachers to increase the digital competence of their students. According to Almerich, Orellana, Suárez-Rodríguez and Díaz-García [63], technological skills are the basis of sound pedagogical methodology, and are a valid model for both pre- and university education. However, pedagogical training is crucial for adequate digital competence of university teachers [42]. As stated by Prendes and Gutiérrez [64], familiarity with a certain methodology does not presuppose its use. Teachers need to be aware of the possibilities that technologies offer, as well as knowing and 
sharing examples of good practices with their students and peers.

\section{CONCLUSION}

In the coming years, advances in technology will continue to influence and transform the different aspects of teachinglearning processes. In fact, there is no single model that can be used definitively in training, either for university classes or for educators. Higher education institutions are faced with new hybrid models, which integrate face-to-face and virtual classes thanks to the possibilities technology offers [65]. This became even more evident in this first half of 2020, due, unfortunately, to the Covid-19 health pandemic. More than ever, education systems must be able to prepare their students to function in this new reality, as well as to be prepared for the next technological revolution [66].

Overall, this study has shown that educators need adequate digital competences to meet the challenges of the technological world. It is a competence that enables them to enrich their teaching and their own professional development, beyond basic digital skills. This review of the literature complements others carried out previously, such as that of Rodríguez-García, Raso and Ruiz-Palmero [67], which focused on teacher-training, and which showed that this subject has become a growing research topic, as it has incited great interest in the international scientific community. Despite the various analyses, not all definitions of the digital competent teacher share the same vision of the profile of a teacher in today's world. Based on Williamson's ideas [68], it is a construct built from a mixture of ideas produced for different purposes and at different times, so that although digital competence and technologies are part of many of the current discourses, they differ substantially in other respects.

As with all research, this report has its limitations. The literature focusing on the digital competence of university teachers is still scarce and, in many cases, based on the analyses of the participants' own self-perception. Furthermore, in the first phase of the review many researchers focused on the competences of Pre-School and Primary teachers, and these studies were therefore discarded. The relative dearth of literature centered on higher education, the variety of frameworks and dimensions that comprise this competence, as well as the predominance of skewed results because of elements of self-perception, has meant that the present review of the literature, even though it has followed a process of systematic and rigorous analysis, has not been able to go beyond a descriptive and integrated examination of the literature. Taking into account the growing trend of this subject, it would be appropriate to explore in future studies the possibility of using meta-analysis techniques that would enrich and provide statistical validity to the results.

A further challenge is that there is no single term in English to refer to digital teaching competences, and it is difficult to include all the literature that addresses this subject. In fact, it is important to stress the large number of articles analyzed from South America. As already mentioned, some of these limitations may consequently lead to the impetus for future research, with new names being included in the review, and the number of researchers extended, to avoid possible biases.

Another important future line of work is to delve deeper into the possibilities of training and evaluation of teaching competences, something that seems to be more common at pre-university levels [69]. In addition to the statistical analysis mentioned above, and beyond the exploration of selfperception, it would be advisable to go further into the analysis of this competence through qualitative research methods, such as case studies or ethnographic methods. Thus, one could analyze, for example, real cases in the use of technology in the teaching-learning processes, what pedagogical approaches are underlying in such uses, the importance teachers attribute to the performance of this digital teaching competence, and to what extent the context favors or determines its performance. All of this would provide a broader perspective. In this sense, this study forms part of an investigation in which, in the future, it will continue to deepen the analysis of the digital teaching competence of university teachers.

Finally, it may also be useful to analyze the role that universities, as institutions, should play. As Pettersson states [70], this is a very important competence that should not be the exclusive responsibility of the teacher. Higher education institutions need to be able to respond to these new demands with adequate digital training for their educators. According to Marín, Vázquez, Llorente and Cabero [71], this is something that is still the exception in teacher-training programs.

\section{ACKNOWLEDGMENTS}

This research was carried out with support from the Research Promotion Plan of the Universitat Jaume I, Spain (Ref.: UJI-A2018-09).

\section{REFERENCES}

[1] J. Voogt, O. Erstad, C. Dede and P. Mishra, "Challenges to learning and schooling in the digital networked world of the 21 st century," Journal of Computer Assisted Learning, vol. 29, no. 5, pp. 403-413, 2013.

[2] A. Ferrari, Digital Competence in Practice: An Analysis of Frameworks. Seville: European Commission, Joint Research Centre (JRC), 2012.

[3] Comisión Europea, Recomendación del Consejo de 22 de mayo de 2018 relativa a las competencias clave para el aprendizaje permanente. Diario Oficial de la Unión Europea, 2018.

[4] E. E. Gallardo-Echenique, J. M. De Oliveira, L. Marqués-Molías and F. M. Esteve-Mon, "Digital Competence in the Knowledge Society," MERLOT Journal of Online Learning and Teaching, vol. 11, no. 1, 2015.

[5] D. Bawden, "Origins and concepts of digital literacy," in Digital Literacies: Concepts, policies and practices. New York: Peter Lang, 2008, pp. 17-32.

[6] A. Martin, "DigEuLit-a European framework for digital literacy: A Progress Report," Journal of eLiteracy, vol. 2, no. 2, pp. 130-136, 2005.

[7] A. W. Bates, Teaching in a digital age. Guidelines for designing teaching and learning, 2015.

[8] M. Gisbert, J. González, and F. M. Esteve, "Competencia digital y competencia digital docente: Una panorámica sobre el estado de la cuestión," Revista Interuniversitaria de Investigación en Tecnología Educativa, no. 0, pp. 74-83. 2016.

[9] R. J. Krumsvik, "Teacher educators' digital competence," Scandinavian Journal of Educational Research, vol. 58, no. 3, pp. 269-280, 2012. 
[10] C. Redecker and Y. Punie, European Framework for the Digital Competence of Educators. DigCompEdu. Seville: European Commission, Joint Research Centre (JRC), 2017.

[11] S. Tewari and M. Birla, "Digital Literacy of Faculty \& Its Relationship with Teaching Learning: A Study on Student's Perspective," Pacific Business Review International, vol. 11, no. 6, pp. 99-108, 2018.

[12] T. J. B. Blayone, O. Mykhailenko, R. vanOostveen, O. Grebeshkov, O. Hrebeshkova and O. Vostryakov, "Surveying digital competencies of university students and professors in Ukraine for fully online collaborative learning," Technology Pedagogy and Education, vol. 27, no. 3, pp. 279-296, 2018.

[13] R. Hall, L. Atkins and J. Fraser, "Defining a self-evaluation digital literacy framework for secondary educators: The DigiLit Lecister project," Research in Learning Technology, no. 22, 2014.

[14] F. Caena and C. Redecker, "Aligning teacher competence frameworks to 21st century challenges: The case for the European Digital Competence Framework for Educators (DigCompEdu)," European Journal of Education, vol. 54, no. 3, pp. 1-14, 2019.

[15] UNESCO, Guidelines on adaptation of the UNESCO ICT Competency Framework for teachers. Moscow: UNESCO Institute for Information Technologies in Education (IITE), 2013.

[16] A. Mattila, "The future educator skills in the digitization era: Effects of technological development on higher education," in Proceedings of 2015 5th International Conference on e-Learning, ECONF, 2016, pp. 212215.

[17] S. Guri-Rosenblit, "E-Teaching in Higher Education: An Essential Prerequisite for E-Learning," Journal of New Approaches in Educational Research, vol. 7, no. 2, pp. 93-97, 2018.

[18] M. Petticrew and H. Roberts, Systematic reviews in the social sciences: A practical guide. Oxford, UK: Blackwell Publishing, 2008.

[19] J. E. Revelo-Rosero, F. I. Revuelta, A. Gonzalez-Perez, "Modelo de integración de la competencia digital del docente universitario para su desarrollo profesional en la enseñanza de la matemática," Edmetic, vol. 7, no. 1, pp. 196-224, 2018.

[20] C. M. Mendieta, "Integración en el contexto de la educación superior pública de Nicaragua: El nuevo modelo educativo de la UNANManagua," Edmetic, vol. 5, no. 2, pp. 29-50, 2016.

[21] L. Bennett, "Learning from the early adopters: Developing the digital practitioner," Research in Learning Technology, vol. 22, no. 1, 2014.

[22] M. McMahon, "Ensuring the development of Digital Literacy in higher education curricula," in Proceedings of ASCILITE 2014 - Annual Conference of the Australian Society for Computers in Tertiary Education, 2014, pp. 524-528.

[23] K. V. Pozos and O. M. Torello, "The digital competence as a crosscutting axis of higher education teachers' pedagogical competences in the European Higher Education Area," in 4th World Conference on Educational Sciences WCES, 2012. pp. 1112-1116.

[24] L. M. Ungerer, "Digital Curation as a Core Competency in Current Learning and Literacy: A Higher Education Perspective," International Review of Research in Open and Distributed Learning, vol. 17, no. 5, pp. 1-27, 2016.

[25] K. Riviou, C. Fernández and M. Garreta, "Design Principles for the online Continuous Professional Development of Teachers," in 2014 14th IEEE International Conference on Advanced Learning Technologies, 2014, pp. 727-731.

[26] M. Savin-Baden, L. Gourlay, C. Tombs, N. Steils, G. Tombs and M. Mawer, "Situating pedagogies, positions and practices in immersive virtual worlds," Educational Research, vol. 52, no. 2, pp. 123-133, 2010.

[27] E. Fernandez-Marquez, J. J. Leiva-Olivencia and E. Lopez-Meneses, "Competencias digitales en docentes de Educación Superior," Revista Digital de Investigación en Docencia Universitaria, vol. 12, no. 1, pp. 213-231, 2018.

[28] R. Goodfellow, "Literacy, literacies and the digital in higher education," Teaching in Higher Education, vol. 16, no. 1, pp. 131-144, 2011.

[29] M. A. Montoro, F. J. Hinojo-Lucena and F. R. Sánchez, "A study on ICT training among faculty members of Spanish faculties of education," New Educational Review, vol. 42, no. 4, pp. 27-39, 2015.

[30] A. V. M. Motta and M. A. De Lima, "O docente do ensino superior inserido na cultura digital, Onde o conhecimento é sempre relativo, provisório e histórico," Espacios, vol. 35, no. 2, 2014.

[31] Ó. Flores and I. del Arco, "Nativos digitales, inmigrantes digitales: Rompiendo mitos. Un estudio sobre el dominio de las TIC en profesorado y estudiantado de la Universidad de Lleida," Bordón. Revista de Pedagogía, vol. 65, no. 2, pp. 59-74, 2013.
[32] E. García, K. Dungay, I. Elbeltagi and N. Gilmour, "An evaluation of the impact of academic staff digital literacy on the use of technology: A case study of UK Higher Education," in Edulearn 13: 5th International Conference on Education and New Learning Technologies, 2013, pp. 2042-2051.

[33] D. Radovanovic, B. Hogan and D. Lalic, "Overcoming digital divides in higher education: Digital literacy beyond Facebook," New Media \& Society, vol. 17, no. 10, pp. 1733-1749, 2015.

[34] C. McLoughlin and M. J. W. Lee, "Pedagogical Responses to Social Software in Universities," in Social Computing: Concepts, Methodologies, Tools, and Applications, 2009, pp. 417-438.

[35] B. Rivas-Rebaque, F. Gértrudix-Barrio, and J. C. De Britto, "La percepción del docente universitario ante el uso y valor de los datos abiertos," Educación XX1, vol. 22, no. 2, pp. 141-163, 2019.

[36] R. M. Marques, "Analysis and Perspectives of Distance Education in Brazilian Higher Education,” Acesso Livre, no. 7, pp. 207-228, 2017.

[37] G. H. Orozco, M. Cabezas, F. Martínez, J. E. Delgado and M. E. Solís, "Determining factors in acceptance of ICT by the University faculty in their teaching practice," in ACM International Conference Proceeding Series, 2016, pp. 139-146.

[38] M. R. Lea, "Reclaiming literacies: Competing textual practices in a digital higher education," Teaching in Higher Education, vol. 18, no. 1, pp. 106-118, 2013.

[39] F. Esteve and M. Gisbert, "El nuevo paradigma de aprendizaje y las nuevas tecnologías," REDU: Revista de Docencia Universitaria, vol. 9, no. 3, pp. 55-73, 2011.

[40] M. Tolic and S. Pejakovic, "Self-assessment of digital competences of Higher Education professors," in 5th International Scientific Symposium Economy of Eastern Croatia-Vision and Growth, 2016, pp. 570-578.

[41] P. Gutiérrez, R. Yuste, S. Cubo and M. Lucero, "Buenas prácticas en el desarrollo de trabajo colaborativo en materias TIC aplicadas a la educación," Profesorado. Revista de Curriculum y Formación del Profesorado, vol. 15, no. 1, pp. 179-194, 2011.

[42] M. Bond, V. I. Marin, C. Dolch, S. Bedenlier and O. Zawacki-Richter, "Digital transformation in German Higher Education: Student and teacher perceptions and usage of digital media," International Journal of Educational Technology in Higher Education, vol. 15, no. 48, 2018.

[43] G. Deumal and M. Guitert, "Digital competence in design education. Case Study of BAU Design College of Barcelona (UVic)," Relatec: Revista Latinoamericana de Tecnología Educativa, vol. 14, no. 2, pp. $51-65,2015$.

[44] Y. Espinosa and L. Llorens, "Validating an instrument to explore leadership capabilities for ICT implementation in education," Relatec: Revista Latinoamericana de Tecnología Educativa, vol. 14, no. 3, pp. 35-47. 2015.

[45] M. R. Fernandez, M. Sanchez-Oro and R. Robina, "La evaluación de la competencia digital en la docencia universitaria: El caso de los grados de empresariales y económicas," Revista Colombiana de Ciencias Sociales, vol. 7, no. 2, pp. 332-348, 2016.

[46] F. X. Carrera and J. L. Coiduras, "Identificación de la competencia digital del profesor universitario: un estudio exploratorio en el ámbito de las Ciencias Sociales," REDU: Revista de Docencia Universitaria, vol. 10, no. 2, pp. 273-298, 2012.

[47] R. Hobbs and J. Coiro, "Everyone Learns from Everyone: Collaborative and Interdisciplinary Professional Development in Digital Literacy," Journal of Adolescent and Adult Literacy, vol. 59, no. 6, pp. 623-629, 2016.

[48] C. Cronin, "Openness and praxis: Exploring the use of open educational practices in higher education," International Review of Research in Open and Distance Learning, vol. 18, no. 5, pp. 15-34, 2017.

[49] N. Duta, "Training Teachers University-Some reflections on the development of digital competence in the knowledge society," in Proceedings of the 6th International Conference on Virtual Learning, 2011, pp. 352-357.

[50] K. V. Pozos and J. Tejada, "Competencias Digitales en Docentes de Educación Superior: Niveles de Dominio y Necesidades Formativas," Revista Digital de Investigación en Docencia Universitaria, vol. 12, no. 2, pp. 59-87, 2018.

[51] A. Rangel and E. A. Peñalosa, "Alfabetización digital en docentes de Educación Superior. Construcción y prueba empírica de un instrumento de evaluación," Pixel-Bit: Revista de Medios y Educación, vol. 43, pp. 9-23, 2013.

[52] G. H. Orozco, M. Cabezas, F. Martínez, and M. A. Mercado-Varela, "Digital competence of the University faculty: Case study of the 
Universidad Nacional de Chimbo razo," in ACM International Conference Proceeding Series, 2016, pp. 147-154.

[53] B. Zempoalteca, J. F. Barragán, J. González and T. Guzmán, "Formación en TIC y competencia digital en la docencia en instituciones públicas de educación superior," Apertura, vol. 9, no. 1, pp. 80-96. 2017.

[54] M. Dorfsman, "El componente vivencial como factor central en la integración de tecnologías para la enseñanza y la investigación," RED: Revista de Educación a Distancia, 29, 2011.

[55] H. Rodríguez, L. F. Restrepo and D. Aranzazu, "Alfabetización informática y uso de sistemas de gestión del aprendizaje (LMS) en la docencia universitaria," Revista de la Educación Superior, vol. 43, no. 171, pp. 139-159, 2014.

[56] A. Wheeler, P. Vlachopoulos and S. Cope, "Creating a culture for critical and situated technology use through effective learning design," in Annual conference of the Australian Society for Computers in Tertiary Education, 2012.

[57] H. Catalano and C. Catalano, "Study on the Use of the Didactic Methodology in the Training of the Native Digital," in Proceedings of the 11th International Conference on Virtual Learning, 2016, pp. 126130.

[58] N. Selwyn, Education and technology. Key issues and debates. London: Continuum, 2011.

[59] E. Katic, 'Preservice teachers' conceptions about computers: An ongoing search for transformative appropriations of modern technologies," Teachers and Teaching, vol. 14, no. 2, pp. 157-179. 2008.

[60] M. J. Rodríguez Conde and A. B. Sánchez, "Competencias docentes del profesor universitario para el uso didáctico de recursos tecnológicos, ante el Espacio Europeo de Educación Superior," Aula, vol. 14, pp. 3150, 2002.

[61] M. Durán, I. Gutiérrez and M. P. Prendes, "Análisis conceptual de modelos de competencia digital del profesorado universitario," Relatec: Revista Latinoamericana de Tecnología Educativa, vol. 15, no. 1, pp. 97-114, 2016.

[62] L. Castañeda, F. Esteve and J. Adell, “¡Por qué es necesario repensar la competencia docente para el mundo digital?," RED: Revista de Educación a Distancia, no. 56, 2018.

[63] G. Almerich, N. Orellana, J. Suárez-Rodríguez and I. Díaz-García, I. "Teachers' information and communication technology competences: A structural approach. Computers \& Education, no. 100, pp. 110-125. 2016.

[64] M. P. Prendes and I. Gutiérrez, "Competencias tecnológicas del profesorado en las Universidades españolas," Revista de Educación, no. 361, pp. 196-222, 2013.

[65] J. M. Duart and S. Mengual-Andrés, "Transformaciones en la universidad hoy: Integración de modalidades formativas," Revista Española de Educación Comparada, no. 26, pp. 15-39, 2015.

[66] M. Ally, "Competency Profile of the Digital and Online Teacher in Future Education," The International Review of Research in Open and Distributed Learning, vol. 20, no. 2, 2019.

[67] A. M. Rodríguez-García, F. Raso and J. Ruiz-Palmero, "Competencia digital, educación superior y formación del profesorado: Un estudio de meta-análisis en la Web of Science," Pixel-Bit: Revista de Medios y Educación, no. 54, pp. 65-82, 2019.

[68] B. Williamson. Making up the "good" teacher. Stirling: University of Stirling, 2013.

[69] J. L. Lázaro-Cantabrana, M. Usart-Rodríguez and M. Gisbert-Cervera, "Assessing Teacher Digital Competence: The Construction of an Instrument for Measuring the Knowledge of Pre-Service Teachers," Journal of New Approaches in Educational Research, vol. 8, no. 1, pp. 73-78, 2019.

[70] F. Pettersson, "On the issues of digital competence in educational contexts a review of literature," Education and Information Technologies, vol. 23, no. 3, pp. 1005-1021, 2018.

[71] V. Marín, A. I. Vázquez, M. C. Llorente and J. Cabero, "La alfabetización digital del docente universitario en el espacio europeo de educación superior," Edutec: Revista Electrónica de Tecnología Educativa, no. 39, 2012.

Francesc M. Esteve-Mon is Commissioner for digital matters of the rector' office and Assistant Professor in the Department of Pedagogy at Universitat
Jaume I, Spain. He teaches in Initial Teacher Education program. Graduated in Education and Educational Psychology, master and $\mathrm{PhD}$ in Educational Technology. He participates in the Teaching, Learning and Technology Research Group (GREAT), and develops his research on digital competence, teacher education, and design-based research. His work has been published in peer-reviewed journals, such as, Journal of Educational Computing Research, and Australasian Journal of Educational Technology.

María Ángeles Llopis Nebot is a Lecturer in the Department of Pedagogy at Universitat Jaume I, Spain. She teaches in Initial Teacher Education program and coordinates the internships of student teachers. Ph.D. in Education at Universitat Jaume I, she develops her research work in GREAT Research Group (Teaching, Learning \& Technology) and EDUBOT (Innovation Group in Educational Robotics and Computational Thinking). Her research interests center on reflective and computational thinking, and digital competence.

Jordi Adell-Segura is the Head of the Center for Education and New Technologies (CENT), and Associate Professor in the Department of Pedagogy at Universitat Jaume I, Spain. Doctor of Philosophy and Education Sciences, he is the coordinator of the Teaching, Learning and Technology Research Group (GREAT). His teaching and research activity focus on educational technology and recently he has published some texts on the use of blockchain in education, and the need for debate on the incorporation of computational thinking in the curriculum of compulsory education. He has also participated in several panels and advisory committees on Technology and Education. 